PATCH ATLAS 
This page intentionally left blank 


\section{Patch Atlas}

INTEGRATING DESIGN PRACTICES

AND ECOLOGICAL KNOWLEDGE

FOR CITIES AS COMPLEX SYSTEMS

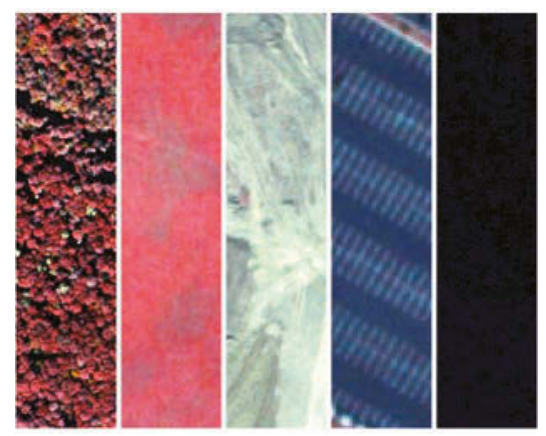

Victoria J. Marshall

Mary L. Cadenasso

Brian P. McGrath

Steward T. A. Pickett 
Frontispiece - Five land cover elements shown as fragments of aerial imagery: woody vegetation, herbaceous vegetation, bare soil, pavement, and buildings

Published with assistance from the foundation established in memory of Calvin Chapin of the Class of 1788 , Yale College.

Copyright (C) 2019 by Victoria J. Marshall, Mary L. Cadenasso, Brian P. McGrath, and Steward T. A. Pickett.

All rights reserved. This book may not be reproduced, in whole or in part, including illustrations, in any form (beyond that copying permitted by Sections 107 and 108 of the U.S. Copyright Law and except by reviewers for the public press), without written permission from the publishers.

Yale University Press books may be purchased in quantity for educational, business, or promotional use. For information, please e-mail sales.press@yale.edu (U.S. office) or sales@yaleup.co.uk (U.K. office).

Designed by Nancy Ovedovitz and set in Scala Sans type by Tseng Information Systems, Inc. Printed in China.

ISBN 978-0-300-23993-5 (paper: alk. paper) Library of Congress Control Number: 2019937271

A catalogue record for this book is available from the British Library.

This paper meets the requirements of ANSI/NISO Z39.48-1992 (Permanence of Paper).

$\begin{array}{llllllllll}10 & 9 & 8 & 7 & 6 & 5 & 4 & 3 & 2 & 1\end{array}$ 